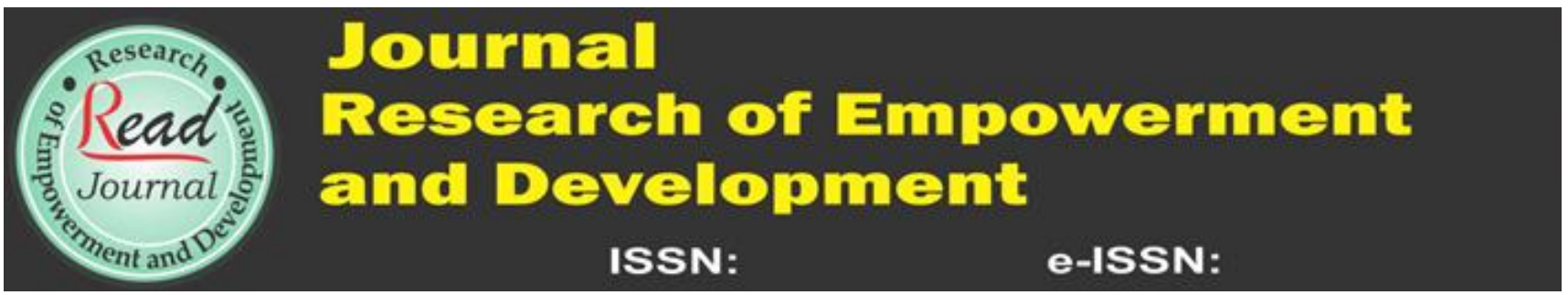

\title{
The Use of Various Substrate Microbial Bamboo Stems for Rice Straw Fermentation and its effect on digestibility and fermentation product of Beef Cattle Ration
}

\author{
Chabib B.H ${ }^{1}$, Sri Rahayu ${ }^{1 *}$ and Muhamad Bata ${ }^{1}$ \\ ${ }^{1}$ Faculty of Animal Science, University of Jenderal Soedirman, Purwokerto_Indonesia \\ *Corresponding author. E-mail: sirahayu27@gmail.com*, muhamadbata@yahoo.com
}

Submitted : July 2019, Accepted: January 2020, Published : March 2020

\section{HIGHLIGHT}

- Bamboo stems contain mixed culture microbial, viz. lactic acid bacteria, Bacillus, Endomycetes lactic and Staphylococcus.

- Fermentation can improve the quality and make rice straw as probiotics carrier

- $\quad$ Fermented rice straw in beef cattle ration can influence digestibility and products fermentation.

\section{Keyword}

Rice-straw; fermentation; microbial-bamboo; beefcattle

\section{ABSTRACT}

This experiment investigated various substrate growth of bamboo stems microbes (BSM) in rice straw fermentation and its effect on dry matter digestibility (DMD), organic matter digestibility (OMD), $\mathrm{NH}_{3}-\mathrm{N}$ and VFA concentration. Materials were rumen fluid of beef cattle from the slaughterhouse. Basal diets consisted of rice straw and concentrate with ratio of $40: 60$ ( $\%$ dry matter) were administered to five treatments namely $\mathrm{P} 0=$ untreated rice straw (control), $\mathrm{P} 1=$ Ammoniated rice straw, fermented rice straw using microbial bamboo stems grown on ammoniated rice straw $(\mathrm{P} 2)$, rice bran (P3) and cassava waste (P4). The experiment used in vitro method was designed with_Completely Randomized Design and the data were analyzed variance. The results showed that the treatment had no significant effect on dry matter digestibility (DMD), organic matter digestibility (OMD), $\mathrm{NH}_{3}-\mathrm{N}$ and VFA concentration $(\mathrm{P}>0,05)$. The fermentation process of microbial bamboo stems in rice straw with a level of $10 \%$ with different substrate did not able to increase the digestibility and products fermentation, but there tends that the rice bran and substrates can increase DMD and $\mathrm{N}-\mathrm{NH}_{3}$ concentration.

\section{Introduction}

Indonesia is the third largest rice-producing country and rice straw after China and India (Sarnklong et al., 2010), and rice straw became the main feed of beef cattle. According to data Badan Pusat Statistik (2011) it is estimated that there are 100.965 million tons of straw production per year. Rice straw is mainly composed of polysaccharides such as cellulose (40\%), hemicellulose (35\%), lignin (10\%), and silica (5\%) (Kogo et al., 2017). The obstacles to utilizing rice straw as feed include the high level of lignification and silicification, the slow and limited ruminal degradation of the carbohydrates, and the low content of nitrogen (Van Soest, 2006). This resulted in , rice straw is poorly fermented, bearing low rates of disappearance in the rumen and low rates of passage through the rumen, reducing feed intake (Sarnklong et al., 2010). Therefore, processing technology is needed to improve the digestibility of rice straw and fermentation using natural inoculums from bamboo stems as an alternative solution.

Various microbes in bamboo stems include Lactobacillus., Streptococcus., 
Lactococcus variants, Bacillus cereus and Staphylococcus and yeast Endomyces lactic (Pato, 2003). Fermentation required inoculum as a substrate for microbial growth prior to fermentation process.

Agro-industrial waste such as rice straw, rice bran, and cassava waste can be used as a substrate for microbial growth in the inoculum because it comprises of carbohydrates that become energy for microbes. Microbes need nutrients for their growth when grown on different substrates because they will secrete different hydrolytic enzymes. This research aims to evaluate microbial bamboo stems grown on different substrates as inoculums in fermented rice straw production and its effect on the digestibility and fermentation products in beef cattle ration

\section{Research methods}

This research was carried out at Feed and Nutrition Laboratory, Faculty of the Animal Science University of Jenderal Soedirman.

Research used in vitro method (Tilley and Terry, 1963) for variables, i.e. dry matter and organic matter digestibility (DMD and OMD) measured in AOAC method (1999), NH3-N concentration with Conway microdiffusion technique (Davis and Smith, 1958) and total volatile fatty acids (VFAs) product with steam distillation method (AOAC, 1999).

Experimental materials. Rice straws were collected from rice-field, air-dried to reach $10 \%$ dry matter (DM), and chopped to a theoretical length of 2 to $3 \mathrm{~cm}$. Rumen fluids were obtained from the slaughterhouse as soon as the cow was slaughtered.
Production of bamboo stems inoculum. A total $100 \mathrm{~g}$ of each ammoniated rice straw mash, rice bran, and cassava waste was added with $1 \mathrm{~g}$ urea, one gram sugar, $5 \mathrm{~g}$ BSM, and water until $60 \%$ moisture was reached. After sterilization, the inoculums were incubated for seven days.

Treatments. Bamboo stem inoculum was used $10 \%$ as much as DM rice straw. The ration was prepared using concentrate and rice straw with a ratio of 60: 40 (\% DM) for five treatments as follow:

$\mathrm{P} 0=60 \%$ concentrate $+40 \%$ untreated rice straw. $\mathrm{P} 1=60 \%$ concentrate + $40 \%$ ammoniated rice straw, $\mathrm{P} 2=60 \%$ concentrate $+40 \%$ fermented rice straw produce by ammoniated rice straw inoculums, $\mathrm{P} 3=60 \%$ concentrate $+40 \%$ fermented rice straw produce by rice brain inoculums, $\mathrm{P} 4=$ $60 \%$ concentrate $+40 \%$ fermented rice straw produce by cassava waste inoculums.

Statistical Analysis. The data were analyzed in a completely randomized design using ANOVA with five treatments and five replicated. The results were presented as the mean values and standard error of the means.

\section{Result and Discussion}

\subsection{Dry Matter and Organic Matter} Digestibility (DMD and OMD)

The highest dry matter digestibility (DMD) and organic matter digestibility (OMD) values were found on P1 (ammoniated rice straw inoculums), namely $33,87 \pm 0,72 \%$ dan $40,27 \pm$ $0.72 \%$, while the lowest was P3 (fermented rice straw with rice bran inoculums) $29,51 \pm 1,95 \%$ and 32,61 $\pm 2.23 \%$ (Table 1 and 2). Analysis of variances informed that the use of inoculum from bamboo stems microbes grown on various substrates for rice straw fermentation had no significant effect $(\mathrm{P}>0.05)$ on DMD and KBO. 
Various types of bacteria and yeast reported to live in the stem of bamboo include Lactobacillus., Streptococcus., Lactococcus variants, Bacillus cereus, Staphylococcus and yeast Endomyces lactic (Pato, 2003). Lactobacillus, Streptococcus, and Lactococcus are lactic acid bacteria (LAB) which play an important role in various food fermentations. LABs are protease and amylase producing bacteria; they have no cellulose or lignin degrading enzyme. While Staphylococci is a facultative anaerobe, it mainly produces lactic acid in the fermentation process (Plata, 2009). Pogoku et al., (2010) reported a bacterial strain isolated from an oil-contaminated soil identified as Staphylococcus sp. Lp12 and it was secreted lipase. Endomyces sp. IFO 0111 yeast is known to produce an extracellular amylase which was proved to production of glucose from starch. This yeast used hydrolysis of starch and Rhizopus sp. (Yamamoto et al., 1964). Brimer et al., (1998) reported that another Endomyces namely E. fibuliger LU677 produced an extracellular beta-glycosidase activity when grown in malt extract broth. Bacillus cereus is a group of ubiquitous facultative anaerobic sporeforming gram-positive rods commonly found in soil (Tallent, 2012). Bacillus sp. is known as a producer of various types of hydrolytic enzymes, but it is unknown whether the bacteria produce degrading lignin enzymes.

Accordingly, fermentation of rice straw using microbial inoculum bamboo stem is evident to produce no significant effect on DMD and OMD due to the presence of cellulose and lignindegrading microbial in bamboo stems, i.e. hydrolyzed lignocellulose in rice straw. MacDonald et al., (1991) informed the growth of $\mathrm{LAB}$ via fermentation requires adequate WSC supplement, and the addition of homofermentative LAB in silages did not effectively promote the fermentation process. Meanwhile, Li et al., (2016) reported that inoculation with hetero and homofermentative LAB had no effects on the DM and ADF content of rice straw silages

Similarly, Amin (2013) on probiotic Bacillus for fermenting rice straw reported 33,22\% DMD. However, Suryapratama (2012) reported that $2 \%$ Saccharomyces cerevisiae in the basal ration contained fermented rice straw using
Phanerochaete chrysosporium produced $49,83 \pm 1,80 \%$ DMD and 52,69 $\pm 1,69 \%$ OMD. Phanerochaete chrysosporium is white-rot fungi that can break down lignin, but it has a low ability to degrade cellulose and hemicellulose so that both cellulose and hemicellulose can be used by rumen microbes and subsequently by the host animal. White-rot fungi, as a wood-decaying basidiomycete and lignocellulolytic microorganism, can decompose and metabolize moniated and fermented rice straw.

\begin{tabular}{|l|c|c|}
\hline \multicolumn{1}{|c|}{ Ration } & $\mathrm{DMD}(\%)$ & $0 \mathrm{MD}(\%)$ \\
\hline $60 \%$ concentrate $+40 \%$ untreated rice straw $(\mathrm{P} 0)$ & $31.40 \pm 1.22$ & $36,50 \pm 1.31$ \\
\hline $60 \%$ concentrate $+40 \%$ ammoniated rice straw/ars $(\mathrm{P} 1)$ & $33,87 \pm 0,72$ & $40,27 \pm 0.72$ \\
\hline $\begin{array}{l}60 \% \text { concentrate }+40 \% \text { fermented rice straw (ars } \\
\text { inoculums } / \mathrm{P} 2)\end{array}$ & $30.34 \pm 1.92$ & $33,75 \pm 1.95$ \\
\hline $\begin{array}{l}60 \% \text { concentrate }+40 \% \text { fermented rice straw (rice bran } \\
\text { inoculums } / \mathrm{P} 3 \text { ) }\end{array}$ & $29,51 \pm 1,95$ & $32,61 \pm 2.23$ \\
\hline $\begin{array}{l}60 \% \text { concentrate }+40 \% \text { fermented rice straw (cassava } \\
\text { waste inoculums } / \mathrm{P} 4)\end{array}$ & $32.91 \pm 1.24$ & $35,91 \pm 1.38$ \\
\hline
\end{tabular}

all plant cell constituents (cellulose, hemicellulose, and lignin) by their enzymes (Eriksson et al., 1990). Karunanandaa et al. (1995) reported that 30-day incubation of rice straw with three white-rot fungi resulted in an enhanced IVDMD by Pleurotus sajor-caju (Table 1)

Rice straw mostly contains cell walls comprised of cellulose, hemicellulose, silica, and lignin. It needs several enzymes to hydrolize these components, viz. cellulase, hemicellulase and ligninase (Sarnklong et al., 2010). Lignin cannot be broken down in the rumen due to the lack of ligninase. Lignin located between the cellulose microfibrils is regarded as the most abundant natural aromatic organic polymer (Iiyama et al., 1990). Silica reduces palatability and degradability of rice straw in the rumen due to its direct action in preventing colonization by ruminal microorganisms (Agbagla-Dohnani et al., 2003).

P1 (ammoniated rice straw) obtained the highest DMD and OMD values when compared to other treatments (Table 1). Treatment P1 used ammoniated rice straw that contained $4 \%$ urea which effectively broke the lignin-cellulose bond and improved the digestibility. Increasing the digestibility of rice straw using urea can stretch the ester bonds between lignin and hemicellulose 
as well as polysaccharide bonds, thereby allowing rumen or microbial enzymes to ferment rice straw (Bata, 2008).

\section{2. $\mathrm{NH}_{3}-\mathrm{N}$ concentration and VFA production}

$\mathrm{NH}_{3}-\mathrm{N}$ and VFA are the main products of microbial fermentation in the rumen derived from feed protein and carbohydrates. VFA is the main energy source for ruminants, and for rumen microbes growth and activity, while $\mathrm{NH}_{3}-\mathrm{N}$ is for microbial protein synthesis. Sutardi (1977) stated that microbial growth was supported by approximately 4-12 $\mathrm{mM} \mathrm{NH} \mathrm{NH}_{3} \mathrm{~N}$ and $80-160 \mathrm{mM}$ VFA. Van Soest (2006) claimed that the growth of rumen microbe declined when $\mathrm{N}^{-\mathrm{NH}_{3}}$ was below $3.57 \mathrm{mM}$.

Analysis of variance showed that various substrates in a bamboo stem microbial inoculum for rice straw fermentation had no significant effect $(\mathrm{P}<0.05)$ on $\mathrm{NH}_{3}-\mathrm{N}$ and VFA despite the ideal amount to support microbial growth and activity (Table 2 ).

However, fermented rice straw (P2, $\mathrm{P} 3$, and $\mathrm{P} 4$ ) may produce higher $\mathrm{NH}_{3}-\mathrm{N}$ and VFA concentrations than untreated (P0) and ammoniated (P1) rice straw (Table 2). Fermented rice straw was suspected to increase microbial population and fermentative process in rumen so it increases fermentation products despite the statistical non-significant effect on N-NH3 and VFA. Seo et al. (2010) informed that microorganisms in direct-fed microbes for ruminants may be classified as lactic acid producing bacteria (LAB), lactic acid utilizing bacteria (LUB), or other microorganisms including species of Lactobacillus, Bifidobacterium, Enterococcus, Streptococcus, Bacillus and Propionibacterium, strains of Megasphaera elsdenii and Prevotella bryantii and yeast products containing Saccharomyces and
Aspergillus. LAB such as lactobacilli and enterococci might prevent ruminal acidosis in dairy cows (Weiss et al., 2008) by facilitating the growth of ruminal microorganisms adapted to the presence of lactic acid in the rumen (Raeth-Knight, 2007) and by stimulating lactic acid utilizing bacteria. Lynch et al. (2002) suggested that yeasts remove oxygen in the rumen and maintain the anaerobic rumen environment. Fermented rice straw that contained microbial bamboo stems in ration may improve ruminal degradationwhich subsequently increases $\mathrm{N}$ -

Tabel 2. $\mathrm{NH}_{3}-\mathrm{N}$ and VFA concentrations of beef cattle ration containing untreated ammoniated and

\begin{tabular}{|l|r|r|}
\hline \multicolumn{1}{|c|}{ Ration } & \multicolumn{1}{|c|}{$\mathrm{NH}_{3}-\mathrm{N}(\mathrm{mM})$} & \multicolumn{1}{|c|}{ VFA (mM) } \\
\hline $60 \%$ concentrate $+40 \%$ untreated rice straw (P0) & $6.64 \pm 0.86$ & $152 \pm 13.04$ \\
\hline $\begin{array}{l}60 \% \text { concentrate }+40 \% \text { ammoniated rice straw/ars } \\
\text { (P1) }\end{array}$ & $7.44 \pm 0.38$ & $166 \pm 8.94$ \\
\hline $\begin{array}{l}60 \% \text { concentrate }+40 \% \text { fermented rice straw (ars } \\
\text { inoculums/P2) }\end{array}$ & $8.16 \pm 0.48$ & $196 \pm 16.73$ \\
\hline $\begin{array}{l}60 \% \text { concentrate + 40\% fermented rice straw (rice bran } \\
\text { inoculums/P3) }\end{array}$ & $9.40 \pm 0.55$ & $203 \pm 18.54$ \\
\hline $\begin{array}{l}60 \% \text { concentrate + 40\% fermented rice straw (cassava } \\
\text { waste inoculums/P4) }\end{array}$ & $10.80 \pm 0.84$ & $182 \pm 14.83$ \\
\hline
\end{tabular}

NH3 and VFA concentrations.

\section{Conclusion}

Ammoniated rice straw, rice bran, and cassava waste can be used as a substrate in BSM inoculums for rice straw fermentation.

The use of $10 \%$ of cassava waste in BSM inoculums for rice straw fermentation tends to increase dry matter digestibility and $\mathrm{NH} 3-\mathrm{N}$ of beef cattle ration

\section{Acknowledgement}

We would like to thank Sawitri for assisting in data collection.

\section{Reference}

Agbagla-Dohnani, A., P. Noziere, B. Gaillard-Martinie, M. Puard and M. Doreau. 2003. Effect of silica content on rice straw ruminal degradation. $J$. Anim. Sci. 140:183-192.

AOAC. 1999. Official, Methods of Assiciation of Chemical Contaminan; 
Drugs. Vol. 2. Assosiation of Official Agicultural Chemist. Inc. Virginia. $\mathrm{P}$ : 932.

Amin, M.; S. D. Hasan; O. Yanuarianto; M.Iqbal. 2015. Supplementation of Bacillus sp. on fermentation and its effect on the quality of ammoniated rice straw. Jurnal Ilmu dan Teknologi Peternakan Indonesia. 1(1) : 8-13.

Badan Pusat Statistik, 2011. Production of Rice, Corn, and Soybeans (temporary figures in 2010 and forecast figures I2011). Official Statistics News No. 18/03/Year. XIV, Maret $1^{\text {st }} 2011$.

Bata, M. 2008. The effect of Molasses on Rice Straw Ammoniation Against Dry Matter and Organic Matter Digestibility In Vitro. Jurnal Agripet 8(2) : 15-20

Brimer, L; M. J. R. Nout; G. Tuncel.1998. Beta-Glycosidase (amygdalase and linamarase) from

Endomyces fibuliger (LU677): formation and crude enzyme properties. Appl Microbiol Biotechnol 49: 182 \pm 188

Davids, N.C. and E.L. Smith. 1958. Methods of Biochem. Anaysis, Vol. 2, $2^{\text {nd }}$ printing. Ed. Gliok, Interscience Publisher, Ins., New York.

Eriksson, K-EL, R. A. Blanchette and P. Ander. 1990. Microbial and enzymatic degradation of wood and wood components. Springer, Berlin, Heidelberg, New York.

Iiyama, K., T. B. T. Lam and B. A. Stone. 1990. Phenolic acid bridges between polysaccharides and lignin in wheat internodes. Phytochem. 29:733-737.

Li, X.; W. Xu; J. Yang; H. Zhao; C. Pan; X. Ding, Y. Zhang. 2016. Effects of applying lactic acid bacteria to the fermentation on a mixture of corn steep liquor and air-dried rice straw. Animal Nutrition 2: 229-233

Lynch, H. A. and S. A. Martin. 2002. Effects of Saccharomyces cerevisiae culture and Saccharomyces cerevisiae live cells on in vitro mixed ruminal microorganism fermentation. J. Dairy Sci. 85:2603-2608.
Karunanandaa, K., G. A. Varga, D. E. Akin, L. L. Rigsby and D. J. Royse. 1995. Botanical fractions of rice straw colonized by white-rot fungi: Changes in chemical composition and structure. Anim. Feed Sci. Technol. 55:179-199

Kogo,T.; Y. Yoshida; K. Koganei; H. Matsumoto; T. Watanabe, J. Ogihara, T. Kasumi. 2017. Production of rice straw hydrolysis enzymes by the fungi Trichoderma reesei and Humicola insolens using rice straw as a carbon source. Bioresource Technology 233: 67-73

MacDonald P.; Henderson A, Heron S.1991. The Biochemistry of silage. Chapter 2:

Crops for Silage. Great Britain:

Chalcome publications.

Pato, U. 2003. The Potency of Lactic Acid Bacteria Isolated from Curd to Reducing Cancer. Jurnal Natur Indonesia. 5(2) : 162-166.

Plata, K.; A. E. Rosato; G. Węgrzyn. 2009. Staphylococcus aureus as an infectious agent: overview of biochemistry and molecular genetics of its pathogenicity. Acta Biochimica Polonica 56 (4):597612

Pogaku, P.; A. Suresh, P. Srinivas; S. Ram Reddy. 2010. Optimization of lipase production by Staphylococcus sp. Lp12. African Journal of Biotechnology 9(6): 882-886

Raeth-Knight, M. L., J. G. Linn and H. G. Jung. 2007. Effect of direct-fed microbials on performance, diet digestibility, and rumen characteristics of holstein dairy cows. J. Dairy Sci. 90: 1802-1809.

Suryapratama, W.; F.M. Suhartati. 2012. Fermentation of Rice Straw Using White rot fungi and Saccharomyces cerevisiae Supplementation and its Effect on Nutrient digestibility In Vitro. Agripet. 12(2).

Sutardi, T. 1995. Increasing production of ruminant livestock through 
ammoniation of low quality fiber feed, defaunation and supplementation of non-degradable protein in the rumen. Hibah Bersaing : a Research Report. Faculty of Animal Science-Bogor Agricultural University-Bogor.

Sarnklong, C.; J. W. Cone; W. Pellikaan; W. H. Hendrik. 2010. Utilization of Rice Straw and Different Treatments to Improve Its Feed Value for Ruminants: A Review. Asian-Aust. J. Anim. Sci. Vol. 23, No. 5 : 680 - 692

Seo, J.K; S-W Kim; M.H Kim; S.D. Upadhaya; D.K. Kam; J.K. Ha.2010. Direct-fed Microbials for Ruminant Animals. Asian-Aust. J. Anim. Sci. 23 (12) : $1657-1667$.

Tallent, S.M. 2012. Bacillus cereus Group of Identification and Isolation

Efficient. Journal of AOAC International 95 (2): 441-451.
Tilley, J. M.A. and R.A. Terry. 1963. A Two Stage Technique for The In Vitro Digestion of Forage Crops. Journal of British Grassland Society. 18(2): 104.

Van Soest, P. J. 2006. Review: rice straw, the role of silica and treatments to improve quality. Anim. Feed Sci. Technol. 130:137-171.

Weiss, W. P., D. J. Wyatt and T. R. McKelvey. 2008. Effect of feeding propionibacteria on milk production by early lactation dairy cows. J. Dairy Sci. 91:646-652.

Yamamoto, T.; F. Hattori; M. Takatsu. 1964. The Effect Of Lipids On Amylolytic Enzyme Production By Endomyces Sp. Bulletin Of The Institute For Chemical Research, Kyoto University 42(4): 252-269 